\title{
THE EFFECTS OF INCLUSIVE EDUCATION ON THE SELF-CONCEPT OF STUDENTS WITH SPECIAL EDUCATIONAL NEEDS
}

\author{
Nurul Aina Zakaria \\ National University of Malaysia, Malaysia \\ E-mail : alwanihusna87@gmail.com
}

\begin{abstract}
Inclusive education is a platform that provides opportunities for students with special educational needs (SEN) to learn in a regular classroom with normal students. However, there are many challenges faced by students with SEN who learn in an inclusive setting, such as negative perception from the mainstream teachers and peers, being bullied and excluded by peers; facing academic issues because of following the regular curriculum like normal students, and lack of support from the parents. The problems occurred has affected the self-concept of students with SEN. Therefore, a study was conducted to explore the impact of inclusive education towards the self-concept of students with SEN in terms of identify the level of self-concept among students with SEN; identify the strongest and the weakest domains of selfconcept; explores the differences of self-concept levels based on gender; and to study the relationship between the level of self-concept with the period of learning in an inclusive education. The respondents consisted of 52 students with SEN, aged between 8 to 15 years old who learn in inclusive settings from 10 schools in the district of Hulu Langat, Selangor. The study was conducted using a set of questionnaires that contains 80 items of Piers-Harris Children's Self Concept Scale that respondents had to answer. The findings showed that the level of self-concept among the students with SEN is at moderate. The study also found that the strongest self-concept domain among the students with SEN is Happiness and Satisfaction (HAP), and the weakest self-concept domain is Popularity (POP). In addition, the results showed that there is no significant difference in the levels of self-concept based on gender, and there is no significant relationship between the levels of self-concept with learning periods in inclusive education.
\end{abstract}

Key words: self-concept, students with special educational needs, inclusive education

Declaration of United Nations (UN) on the Rights of Humanity in 1948 puts education as a human right regardless of age, gender, or race (Md. Amin Kasba, Safani Bari, Mohd. Hanafi \& Mohd. Mokhtar, 2009). In Malaysia, policies and regulations have been established to fight for the rights of people with special educational needs (SEN) in securing equal education through the Education Act 1996, Rules of Special Education, 1997 (Abdul Rahim \& Muhammad Khairul, 2013), and the National Education Blueprint Malaysia (Azad Athahiri \& Norsayyidatina, 2010).

Policies and legislation have provided an opportunity for students with SEN to get equal education like normal students. Arising from this, the inclusive education program has been introduced to allow students with SEN to be placed in regular classes to study with normal students and taught by mainstream education teacher (Abdul Rahim \& Muhammad Khairul, 2013; Pijl, Meijer \& Hegarty in Hofman, 2014), According to Hofman (2014), the placement of students with SEN in inclusive education has become a major educational mission in many countries.

Salamanca (1994) also supports an inclusive education as a program that places students with SEN with normal students in the same class (Lewis \&
Doorlag, 2006 \& Murnie, 2013). According to Friend (2005) in Peterson (2011), students with SEN are those who attend the inclusive education appropriate to their level regardless of physical, mental or developmental delay.

In the current era, inclusive education does not only provide spaces for students with SEN to build friendships with normal students and learn in an environment of normal (Heiman in Alev Girli, 2007), the students with SEN can emulate the positive behavior of peers, be part of the community, and develop their potential in academic and non-academic aspects (Kucuker \& Tekinarslan, 2015). Effective inclusive education clearly benefit students with SEN, because they can enhance their potential in all aspects. This indirectly helps in forming a positive self-concept and make disciples of people who are happy and successful.

According to Rogers (1951), self-concept encompasses beliefs, feelings, perceptions, attitudes and values that uphold an individual. In addition, selfconcept also means thinking about yourself, and other people's thinking towards the individual. Self-concept is divided into two types: positive and negative selfconcept. Individuals who have a negative self-concept are those who are not excited, irritable, and often associated with failure. While individuals who have 
positive self-concept are those who are always happy, not easily deterred, optimistic and are often associated with success. Therefore, teachers should be concerned about the development of self-concept of students in school so that a positive self-concept can be formed.

Self-concept of students in the school can be influenced by people who were in the vicinity of the students, teachers, parents and friends. Teachers can bring a huge influence in the formation of self-concept of students (Azizi \& Jaafar Sidek in the study Nurul Ain \& Azizi Yahaya, 2012) as the learning process in schools involves many interactions between teachers and students. In addition, the social environment, acceptance or allowance to students also influences the student's self-concept.

\section{Figure 1: Conceptual Framework}

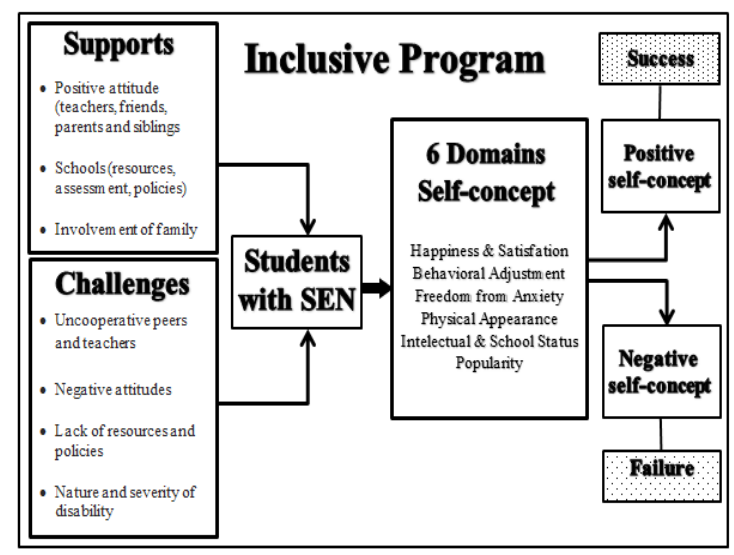

Figure 1 refers to the conceptual framework to guide the study. The framework helps us to understand how supports and challenges that are given to the students with SEN will have an impact to his or her self-concept in an inclusive environment. Figure 1 shows that parents, teachers and peers play a role in the formation of self-concept of students with SEN in inclusive education. Supports that are given to the students will leads to a successful life, while failure occurs when there are various obstacles given to the students.

\section{Figure 2 : Maslow Hierarchy of Needs} (Maslow, 1954)

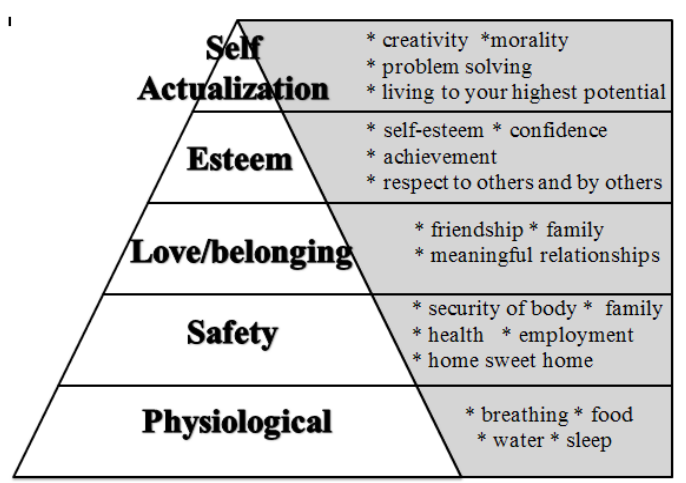

In this study, humanistic learning theory by Maslow serves as the backbone of the study. Figure 2 shows the five levels of hierarchy of needs in which introduced by Maslow (1954). This model shows the hierarchy of human needs in order to be happy and successful in life. Maslow (1954) in Mazlina (2014) states that a person will reach the maximum satisfaction if all five stages of the necessities are met. This matter is closely related to a person's self-concept as when the necessities of life are met, then a positive self-concept is formed.

Furthermore, a positive self-concept can also be fostered through motivation provided to students. If students have motivation, students will generate positive action. In this study, the motivation exists when a person's needs are met in all levels of Maslow's hierarchy (in the study of Fatima, 2014). Therefore, the theory of Maslow's hierarchy of needs is suitable to serve as a guide for this study.

Although inclusive education has longestablished in Malaysia, there are still many obstacles in implementing the program in schools. Typically, students with SEN attendance are often not accepted by teachers and peers (Garguilo in Supiah, 2010). Mainstream education teachers attitudes that are biased or unfair to students with SEN often occurs when students are unable to follow the level or standard of learning areas (Richel, 2014). Therefore, students with SEN have to follow the curriculum and the same test as normal students without any modification according to the level and needs (Mohd. Najib \& Sanisah, 2006; Supiah, 2010).

Besides having problems academically, students with SEN do not have many acquaintance, and its presence is often not required. In addition, students with SEN also found to be less interactive with peers but only interact with teachers (Koster, Pijl, Nakken \& Van Houten, 2010). Other than that, the family background of the students could also cause a negative impact on the development of the students' self-disciple (Dyson in Sternke, 2010).

The problems faced by students with SEN in an inclusive education have affected the student selfconcept, social behavior, and student achievement in academics (Hofman \& Judith, 2014). Consequently, students become unhappy, low self-esteem and are not motivated to learn. In addition, students also often act to isolate themselves from their friends because they feel themselves unnecessary, thus making them frequently involved in disciplinary problems.

Consequently, it is important for teachers to develop strategies and good planning so that teaching and learning activities in school help to boost the selfconcept of students, especially students with SEN. This is because, the self-concept of students with SEN 
proved to be lower than normal (Montogomery in Sternke study, 2010). Schmidt \& Cagran study (2008) also found that hearing impaired students also have lower academic and social perception than normal students.

A study was conducted to examine the effects of self-concept of students with SEN in the inclusive education. Among the objectives of the study are: (1) Identify the level of students with SEN self-concept; (2) Identify the strongest and the weakest self-concept domains among students with SEN; (3) Review the differences in the level of self-concept of students with SEN based on gender; (4) To study the relationship between the period of study in an inclusive education with students with SEN level of self-concept.

\section{METHOD}

The study was conducted on 52 students with SEN aged 8 to 15 years from 10 schools in the district of Hulu Langat, Selangor. The instrument used in this research is Piers-Harris Children's Self-Concept Scale (First-Edition) 80 items, consisting of six domains, namely, Happiness and Satisfaction (HAP), Behavioral Adjustment (BEH), Freedom from Anxiety (FRE), Physical Appearance (PHY), Intellectual \& School Status (INT) and Popularity (POP). This instrument has two options, "Yes" or "No". In this study, respondents were given 15 minutes to answer the questionnaire provided and guidance is given to students in need. Teachers provide guidance by reading the questions clearly and loudly so that students understand the question.

For the determination of self-concept marks, marks " 1 " was given if the respondent gives a positive sign on that item, while marks " 0 " was given if the respondent entered a negative item. Examples of items are shown in Table 1.

Table 1 : Piers-Harris Children's Self-Concept Scale Items

\begin{tabular}{|c|c|c|c|}
\hline No. & Item & Yes & No \\
\hline 1 & I am good hearted & & \\
\hline 2 & I am happy & & \\
\hline 3 & I hate school & & \\
\hline 4 & I quarrel all the time & & \\
\hline
\end{tabular}

In addition, the determination of the level of self-concept refers to the interpretation of the scale as shown in Table 2 (Rohany \& Lee, 2013).
Table 2 : Piers-Harris Interpretation Scale

\begin{tabular}{cl}
\hline Scale & Interpretation \\
\hline$<\mathbf{3 9}$ & Poor \\
$\mathbf{4 0 - 5 9}$ & Moderate \\
$>\mathbf{6 0}$ & Good \\
\hline
\end{tabular}

A pilot study was conducted on 30 students with SEN from 3 schools and value reliability coefficient "Alpha" obtained is 0.75 . Data were analysed using descriptive and inferential statistics.

For data analysing, researchers compare the mean score of student's self-concept for answering research question 1 (Table 4) and 2 (Table 5). The Independent T-Test was used to compare the mean scores based on the gender to answer research question 3 (Table 6), and Pearson Correlation Test was used to answer research question 4 (Table 7).

\section{FINDINGS AND DISCUSSION}

Findings

Respondent Demographics

Table 3 : Respondent Demographics Analysis

\begin{tabular}{lrrr}
\hline Items & Classification & $\mathbf{n}$ & $\mathbf{\%}$ \\
\hline Gender & Male & 38 & 73.1 \\
Age & Female & 14 & 26.9 \\
& 7-9 Years Old & 2 & 3.8 \\
Race & 10-12 Years Old & 32 & 61.5 \\
& 13-15 Years Old & 18 & 34.5 \\
& Malay & 32 & 61.5 \\
& Chinese & 14 & 26.9 \\
The period & Indian & 4 & 7.7 \\
of study in & Others & 2 & 3.8 \\
inclusive & $<1$ Years Old & 2 & 3.8 \\
education & 1-2 Years Old & 37 & 71.2 \\
\hline
\end{tabular}

Table 3 shows the majority of respondents were Malays $(\mathrm{n}=32)$ and the number of male $(\mathrm{n}=38)$ were more than female students $(n=14)$. Most of the respondents aged 10 to 12 years $(n=32)$, while the majority of students learn in an inclusive education in the next 1 to 2 years $(n=37)$.

Students with SEN Self-Concept

Table 4 : Self-Concept Analysis

\begin{tabular}{lc}
\hline \multicolumn{1}{c}{ Levels of Self-Concept } & $\%$ \\
\hline Poor & 7.69 \\
Moderate & 69.23 \\
Good & 23.08 \\
\hline
\end{tabular}


Table 4 shows the level of self-concept among students with SEN. According to Table 4, there were $69.23 \%$ of the students with SEN have a moderate self-concept level, followed by $23.08 \%$ a good level and $7.69 \%$ poor level. This finding shows that the majority of students with SEN are at a moderate level.

This finding is a positive sign that the students could have a better self-concept if more support and motivations are given. Therefore, teachers in schools should show intensive efforts in creating a learning environment that is Persons with Disabilities (PWDs) friendly so that students can benefit from an inclusive education.

In addition, teachers can also practice methods of teaching and learning in the form of Universal Design Learning (UDL). UDL is learning curriculum developed for the benefit and opportunity for all individuals to learn. Learning through UDL, teachers develop strategies, approaches, teaching materials and flexible methods of assessment that can be adapted and adjusted to individual needs (Kurtts, 2006).

\section{Identifying the Strongest and the Weakest Self- Concept Domains.}

Table 5: Score Analysis of 6 Domains of SelfConcept

\begin{tabular}{lcl}
\hline 6 Domains of Self-Concept & $\%$ & Interpretation \\
\hline $\begin{array}{l}\text { Happiness and Satisfaction } \\
\text { (HAP) }\end{array}$ & 80.0 & Good \\
$\begin{array}{l}\text { Behavioral Adjustment } \\
\text { (BEH) }\end{array}$ & 75.0 & Good \\
$\begin{array}{l}\text { Freedom from Anxiety } \\
\text { (FRE) }\end{array}$ & 57.1 & Moderate \\
$\begin{array}{l}\text { Popularity (POP) } \\
\text { Physical Appearance (PHY) }\end{array}$ & 61.5 & Good \\
$\begin{array}{l}\text { Intellectual \& School Status } \\
\text { (INT) }\end{array}$ & 60.0 & Good \\
\hline
\end{tabular}

Student Self-Concept Difference Based on Gender

Table 6: Independent T-Test Level of Self-Concept across Gender

\begin{tabular}{lccccc}
\hline Gender & $\mathrm{n}$ & Mean & $\mathrm{SD}$ & $\mathrm{t}$ & Sig. \\
\hline Male & 38 & 52.21 & 6.995 & -.356 & .723 \\
Female & 14 & 53.07 & 9.499 & & \\
\hline
\end{tabular}

Relationship between the Periods of Study in an Inclusive Education with Students' Self-Concept Level

Table 7 : Pearson Correlation Test on the relationship between the periods of study in an inclusive education with student's levels of self-concept

\begin{tabular}{lccc}
\hline Manipulated Variables & r & Sig. & $\mathbf{n}$ \\
\hline $\begin{array}{l}\text { Periods of study in inclusive } \\
\text { education with level of self- } \\
\text { concept }\end{array}$ & 0.102 & 0.474 & 52 \\
\hline
\end{tabular}

\section{Discussions}

Table 5 above shows six domains of PiersHarris self-concept and the mean scores obtained by the respondents. The findings indicate that the most powerful self-concept domain among the students with SEN is HAP (80\%), while the weakest domain is POP $(50 \%)$.

Overall, the domains of FRE and POP are at a moderate level, while other self domains HAP, BEH, PHY, and INT are at a good level. This is supported by studies (Koster, Timmerman, Nakken \& Van Houten, 2009) that most students with SEN have a positive social perception, and have a good interaction and acceptance from peers.

Based on this finding, it can be said that students with SEN are happy and satisfy to learn in an inclusive education because they have the opportunity to learn with peers in the normal setting. This is supported by studies (Kamaliah \& Wan Amimah, 2010) that students with SEN were happy in the inclusive education as they can learn and communicate with peers and teachers. In the study done by Huei (2009), found that the inclusive environment that provides more attention has positively impacted a student with SEN to become happier, gets more individual instruction and attention, and no longer getting into trouble.

The researchers also concluded that the lowest self-concept domain popularity is influenced by peer acceptance of students with SEN in the classroom. Besides that, negative perception and acceptance from teachers and peers has weaken the self-concept of students with SEN (Bukowski, Hoza B. \& M. Boivin, 1993; Taylor, \& Spratt, 2010).

Table 6 shows that there was no significant difference in the level of self-concept of students with SEN based on gender, $\mathrm{t}(50)=-.356$, and sig. $=0.723$ $(\mathrm{p}>0.05)$. In terms of the mean shows that female have a score $($ mean $=53.07, \mathrm{SD}=9499)$ which was higher than male $($ mean $=52.21, \mathrm{SD}=6,995)$. However, this difference was not significant. This means that the null hypothesis that there is no significant difference 
between the levels of self-concept based on gender can be accepted.

Although the findings of this study showed no significant association level of self-cross-gender, other studies have shown that girls have self-concept, confidence and discipline that are lower than boys (Marsh in the study of Miller, 2000; Bear, Clever \& Proctor, 1991; Fontana \& Obidigbo in Aihie study, 2009). Physically, the female often worry about their physical than male students (Saskatchewan Education, 1991).

Table 7 shows that there is no significant relationship between the periods of study in an inclusive education with the self-disciple, with $\mathrm{r}=$ 0.102 and $\operatorname{sig}=0.474(p>0.05)$. The positive strength of the relationship is very weak. This indicates that the null hypothesis that there is no significant relationship between the study periods in an inclusive education with the students with SEN level of self-concept can be accepted.

Although the results showed no significant correlation between the period of learning in an inclusive education with the students with SEN level of self-concept, study Daniel \& King in Caleigh (2013) proven that the self-concept of students with SEN depends on the age of the students. The older students were found to have more positive selfconcept than younger students. Many other studies have also proven that the self-concept of students with SEN increase from year to year (Cesar \& Santos, 2006), while students with SEN in secondary schools have higher confidence level than students in primary school (Johnson, Johnson \& Rynders in Caleigh, 2013).

This study is expected to be beneficial to the teachers in schools to be more sensitive to the needs of students with SEN. Curriculum, teaching and assessment methods should be adjusted according to the level and needs of the students, in order to create a learning environment that is harmonious, safe and comfortable (Bucholz, J. L. \& Sheffler, J. L. 2009). In addition, teachers and parents need to provide support and motivation to the students so that students can excel (Kucuker \& Tekinarslan, 2015 \& Loh, 2006). Furthermore, the joint venture and a good relationship between special education teachers and mainstream teachers should be established through discussion, sharing of knowledge and teaching materials so that inclusive educations can work better (Abdul Rahim \& Muhammad Khairul, 2013; Glatthorn et al., 2006; Glickman et al., 1998).

The Ministry of Education (MOE) should also be more aware of the needs in inclusive education in terms of budget preparation, labor, facilities and so on. In addition, the monitoring inclusive schools program shall be run by the Ministry of Education to ensure inclusive education running in a systematic and effective manner.

On behalf of the State Education Department (NRD), various training and courses about inclusive education and how to handle students with SEN should be provided for teachers in schools. Adequate training will have a positive impact on the attitudes and perspectives of general education teachers on inclusive education and students with SEN, besides smoothen the implementation of inclusive educations in schools (Prinsloo in the study Richel, 2014).

In addition, programs or activities planned in schools should involve all children regardless of their status and enhance positive self-concept in students. Among the programs that can be held is storytelling, singing, camping, sports days and others.

Parents should also be actively involved in the Parent Teacher Association (PTA) of the school in order to jointly develop activities in accordance with the needs of their children, as well as to strengthen the relationship between parents, teachers and students. Good relationships are formed indirectly will influence the attitudes and behaviour of pupils at the school. Moreover, encouragement, support and motivation should be given to children with SEN so that a positive self-image can be formed in students, in order to improve their academic achievement (Azizi Yahaya, Saiffuddin Ismail, Amir Hamzah \& Halimah, 2010). This is because the attitudes and perceptions of parents may have an impact on the formation of the self-image of students (Raviv \& Stone, 1991 in Anu, 2002)

\section{CONCLUSION AND SUGGESTION}

An effective inclusive education capable of forming a positive self-concept, and increase the potential of students with SEN as a whole. Steady cooperation, as well as continued support of all parties, including administrators, teachers, parents and the local community are needed to establish an effective inclusive education. It is hoped that an inclusive education manage to eliminate the gap and the negative stigma against individuals with special needs, as they are also entitled to be successful and happy like other people.

As for proposed extension, a study that explores the differences of the self-concept levels among students with SEN in government-aided schools and students with SEN in private schools can be carried out to see to what extent inclusive education at schools have an impact on the level of self-concept of students with SEN. 


\section{REFERENCES}

Azizi Yahaya, Sharifuddin Ismail, Amir Hamzah \& Halimah. (2010). Hubungan Di Antara Konsep Kendiri Dengan Kemahiran Komunikasi Terhadap Pencapaian Akademik Pelajar Di Sekolah Menengah Di Johor Bahru. Universiti Teknologi Malaysia. Institutional Repository.

Azad Athahiri b. Anuar \& Norsayyidatina Che Rozubi. (2010). Keperluan Pendidikan Inklusif Dalam Program Pendidikan Arus Perdana Di Malaysia. Bangi. UKM.

Abdul Rahim b. Hamdan \& Muhamad Khairul Anuar b. Hussin. (2013). Persepsi Guru Aliran Perdana Terhadap Inklusif. Fakulti Pendidikan, Universiti Teknologi Malaysia. 2nd International Seminar On Quality And Affordable Education.

Alev Girli. (2003). Effective Social Interaction Strategies For Inclusive Settings. Early Childhood Education Journal 35(5):405-411.

Aihie, O. N. (2009). Effects Of Peer Group Counselling And Sex On The Self-Concept Of Secondary School Adolescents: Implications For Counselling. Edo Journal Of Counselling, 2(2), 189-198.

Anu, L. (2002). Self-Concept Of Children In Special And Regular Education. Department Of Special Education University Of Jyväskylä.

Bukowski W.M., Hoza B., Boivin M. (1993). Popularity, Friendship, and Emotional Adjustment during Early Adolescence. Department of Psychology, Concordia University.

Bucholz, J. L., \& Sheffler, J. L. (2009). Creating A Warm And Inclusive Classroom Environment: Planning For All Children To Feel Welcome, Electronic Journal For Inclusive Education, Vol. 2, No. 4.

Bear, G.G., Clever, A., Proctor, W. A. (1991). Self- Perception Of Non-Handicapped Children And Children With Learning Disabilities In Intergrated Classes. Journal of Special Education, 24, 409-426.

Caleigh C. H. (2013). The Effects of Inclusion Practices on the Emotional Growth and Academic Achievement of Elementary Students. The Evergreen State College.

Cesar, M., \& Santos, N. (2006). From Exclusion to Inclusion: Collaborative Work Contributions to More Inclusive Learning Settings. European Journal Of Psychology Of Education, 21(3), 333 346.

Fatimah bt. Affendi. (2014). Tahap Kepuasan Kerja Dan Komitmen Organisasi Dalam Kalangan Guru Kolej Vokasional: Pendekatan Structural Equation Model. Fakulti Pendidikan Teknikal Dan Vokasional Universiti Tun Hussein Onn Malaysia.
Glatthorn, A. A., Boschee, F., Whitehead, B.M. (2006) Curriculum Leadership Development And Implementation. California: SAGE Publications.

Glickman, C. D., Gordon, S. P., Ross-Gordon, J. M. (1998). Supervision Of Instruction A Developmental Approach. 4th Ed. USA. Allyn And Bacon.

Hofman R. H. \& Judith S. Kilimo. (2014). Teachers' Attitudes And Self-Efficacy Towards Inclusion Of Pupils With Disabilities In Tanzanian Schools. Journal Of Education And Training. Vol 1, No 2.

Huei L.W. (2009). Should All Students with Special Educational Needs (SEN) Be Included in Mainstream Education Provision? - A Critical Analysis. Department of Communication, Faculty of Social science. International Education Studies. Vol. 2, No. 4.

Kamaliah bt. Muhammad \& Wan Amimah bt. Wan Mahmud. (2010). Pelaksanaan Program Pendidikan Inklusif Murid Autistik Di Sebuah Sekolah Rendah : Satu Kajian Kes. Proceedings of The 4th International Conference on Teacher Education; Join Conference UPI \& UPSI Bandung, Indonesia, 8-10 November 2010.

Kucuker S. \& Tekinarslan I. C. (2015). Comparison Of The Self-Concepts, Social Skills, Problem Behaviors, And Loneliness Levels Of Students with SEN In Inclusive Classrooms. Department Of Special Education, Faculty Of Education, Pamukkale University.

Kurtts, S. A. (2006). Universal Design for Learning in Inclusive Classrooms, Electronic Journal for Inclusive Education, Vol 1, No. 10.

Koster M., Pijl S. J., Nakken H., \& Van Houten E. J. (2010). Social Participation of Students with SEN in Regular Primary Education In The Netherlands. International Journal Of Disability, Development And Education Vol. 57, No. 1, 59-75.

Lewis, RB \& Doorlag, D. 2006. Teaching Special Students In General Education Classroom. Upper Saddle River, NJ: Pearson.

Loh S. C. (2006). The Relationship between SelfConcept and the Learning Achievement Of Malaysian Students With Mild Learning Disabilities. Jurnal Pendidikan, Universiti Malaya.

Maslow, A. (1954). Motivation And Personality. New York : Harper \& Row Publishers.

Miller R. (2000). Self-Concept and Students with Disabilities in Tertiary Education. The University Of Sydney. 
Murnie bt. Hassan. (2013). Perlaksanaan Program Inklusif Bagi Pelajar Pendidikan Khas Bermasalah Pembelajaran Di Program Intergrasi. Fakulti Pendidikan Universiti Teknologi Malaysia.

Md. Amin b. Kasbin, Safani b. Bari, Mohd. Hanafi b. Mohd. Yasin \& Mohd. Mokhtar b. Tahar. (2009). Pembinaan Sistem Sokongan Dan Jalinan Kolaborasidalam Perlaksanaan Program Inklusif Pelajar Bekeperluan Khas : Satu Kajian Kes Di Sebuah Sekolah Menengah Program Integrasi Bermasalah Pembelajaran Di Negeri Johor. Fakulti Pendidikan, Universiti Kebangsaan Malaysia.

Mohd Najib b. Ghafar \& Sanisah bt. Jahaya. 2006. Bias Pengajaran Guru Dalam Pelajaran Khas Dan Pelajaran Normal. Sabah : Annual Conference On Teacher Education.

Mazlina bt. Sulaiman. (2014). Hubungan Tekanan Dengan Komitmen Dan Kepuasan Kerja Dalam Kalangan Guru Program Pendidikan Khas Integrasi Bermasalahan Pembelajaran Di Empat Buah Sekolah Rendah Daerah Pontian. Fakulti Pendidikan. Universiti Teknologi Malaysia. Tesis Tidak Diterbitkan.

Nurul Ain bt. Hamsari \& Azizi b. Yahaya. (2012). Peranan Motivasi Pembelajaran, Gaya Keibubapaan Dan Sikap Dengan Pencapaian Akademik. Journal Of Educational Psychology \& Counseling, Vol. 5, 30-57.
Rohany bt. Nasir \& Lee S. L. (2013). The Relationship between Self-Concept and Career Awareness amongst Students. Canadian Center Of Science And Education. Asian Social Science. Vol. 9, No. 1.

Richel C. D. (2014). Teachers' Knowledge And Attitude Towards Inclusive Education: Basis For An Enhanced Professional Development Program. Ifugao State University. International Journal Of Learning \& Development. Vol. 4, No. 4.

Rogers, C. R. (1951a). Client-Centered Therapy. Boston: Houghton Mifflin.

Sternke J. C. (2010). Self-Concept And Self-Esteem In Adolescents With Learning Disabilities. University Of Wisconsin-Stout.

Supiah bt. Saad. (2010). Komitmen Dan Peranan Guru Dalam Pelaksanaan Pendekatanpendidikan Inklusif Di Malaysia. Jabatan Pendidikan Khas, Kementerian Pelajaran Malaysia.

Saskatchewan Education (1991). Gender Equity: Policy And Guidelines For Implementation. Retrieve on August 2016 from http://www.saskatchewan.ca/ 